\title{
Transfer of natural radionuclides from soil to the grass around uranium mine area Žirovski vrh, Slovenia
}

\author{
P. Jovanovič \\ Institute of Occupational Safety, Chengdujska street 25, 1260 Ljubljana-Polje, Slovenia \\ e-mail: peter.jovanovic@zvd.si
}

\begin{abstract}
Uranium mine Zirovski vrh in Slovenia was closed in the year 1993. In the past years a lot of work was done for restoration of the area around the mine. There are two tailing sites, Jazbec and Boršt, filled with material with high specific activity of ${ }^{226} \mathrm{Ra}$. Tailings are covered by different layers of clay and soil in depth of $2 \mathrm{~m}$ for reducing radon exhalation rate. Gras, growing on the surface of tailing sites has been used as fodder for domestic animals. We were interesting about the amount of the specific activity of natural radionuclides ${ }^{238} \mathrm{U},{ }^{226} \mathrm{Ra}$ or ${ }^{210} \mathrm{~Pb}$, transferred from the covering soil on the tailing to the grass on the surface area. The transfer factors of naturally occurring radionuclides have not been studied to the same extent as their artificial counterparts, but some comprehensive investigations have been done by various institutions around the world. In case of ${ }^{226} \mathrm{Ra}$ calculated values are two times or four times bigger than measured. For ${ }^{210} \mathrm{~Pb}$ measured values are up to hundred times bigger than calculated. The reason for that is radon in the air, decays to the ${ }^{210} \mathrm{~Pb}$, deposited on the grass and not ${ }^{210} \mathrm{~Pb}$ coming from the soil.
\end{abstract}

\section{INTRODUCTION}

Uranium mine Žirovski vrh in Slovenia was closed in the year 1993. In the past years a lot of work was done for restoration of the area around the mine. There are two tailing sites, Jazbec and Boršt, filled with material with high specific activity of ${ }^{226} \mathrm{Ra}$ [1]. Tailings are covered by different layers of clay and soil in depth of $2 \mathrm{~m}$ for reducing radon exhalation rate. Gras, growing on the surface of tailing sites has been used as fodder for domestic animals. We were interesting about the amount of the specific activity of natural radionuclides ${ }^{238} \mathrm{U},{ }^{226} \mathrm{Ra}$ or ${ }^{210} \mathrm{~Pb}$, transferred from the covering soil on the tailing to the grass on the surface area. We compare these results with the area close to tailings and with area far away from tailings.

\subsection{Transfer factor}

The transfer of artificial radionuclides has been studied over the last 30 years [2]. In last decade the interest in radiological assessments of the discharges of naturally occurring radionuclides has increased in terms of both current releases from industrial sites and from the presence of historical contamination in the soil. Assessments based on measurements in environmental materials are complicated by the widespread presence of these radionuclides naturally in the environment, so that it may be difficult to determine the effect of a practice against this natural background. Naturally occurring radionuclides may vary by three orders of magnitude, what complicates predictions of radiological impact of industrial practices. Field studies of the transfer of ${ }^{210} \mathrm{~Pb}$ along terrestrial foodchains is more complicated because this radionuclide is formed continually in the atmosphere following the decay of radon gas. 
Table 1. Transfer factor soil - plant (TF).

\begin{tabular}{|l|c|c|}
\hline Source & IAEA [2] & NRPB [3] \\
\hline Radionuclide & $(\mathrm{Bq} / \mathrm{kg})_{\mathrm{rd}} /(\mathrm{Bq} / \mathrm{kg})_{\mathrm{zd}}{ }^{*} 10^{-4} \quad a$ \\
\hline${ }^{238} \mathrm{U}$ & $230(23-2300)$ & 40 \\
\hline${ }^{226} \mathrm{Ra}$ & $800(160-4000)$ & 40 \\
\hline${ }^{210} \mathrm{~Pb}$ & 11 & $400(150-1500)$ \\
\hline
\end{tabular}

zd -soil, dry, rd - plant, dry

${ }^{a}(\mathrm{~Bq} / \mathrm{kg}) \mathrm{rd} /(\mathrm{Bq} / \mathrm{kg}) \mathrm{zd}-$ calculated on dry mass of soil and plant.

Table 2. Specific activities of natural radionuclides ${ }^{238} \mathrm{U},{ }^{226} \mathrm{Ra}$ and ${ }^{210} \mathrm{~Pb}$ in soil samples.

\begin{tabular}{|l|c|c|c|}
\hline $\begin{array}{l}\text { Radionuclide/Location } \\
\text { Refference }\end{array}$ & $\begin{array}{l}\text { Slovenia }(\mathrm{Bq} / \mathrm{kg}) \\
{[4-7]}\end{array}$ & $\begin{array}{c}\text { Surroundings of mine } \\
(\mathrm{Bq} / \mathrm{kg})[10]\end{array}$ & $\begin{array}{l}\text { Covering layer }(\mathrm{Bq} / \mathrm{kg}) \\
{[8,9]}\end{array}$ \\
\hline${ }^{238} \mathrm{U}$ & $51.5(37.5-71.9)$ & $64.1(44.5-81)$ & $82.3(69.6-99.7)$ \\
\hline${ }^{226} \mathrm{Ra}$ & $35.3(25.9-52.6)$ & $76.4(62.5-98.5)$ & $54.8(51.2-57.8)$ \\
\hline${ }^{210} \mathrm{~Pb}$ & $89.9(45.8-141.7)$ & $105,3(67.5-130)$ & $70,7(59.1-76.8)$ \\
\hline
\end{tabular}

\subsection{Transfer factor soil - plant (TF)}

Transfer factor soil - plant (TF) defined as quotient between activity concentration of radionuclide $\mathrm{c}_{i r-d / w}$ (in Bq/kg dray or wet mass) in edible parts of the plant and activity concentration of radionuclide $\mathrm{c}_{i z-d}$ (in Bq/kg dry mass) in soil $[2,3]$ :

$$
T F=\frac{c_{i r-d / w}(\mathrm{~Bq} / \mathrm{kg})}{c_{i z-d}(\mathrm{~Bq} / \mathrm{kg})},
$$

where $\mathrm{i}=1,2,3$ for ${ }^{238} \mathrm{U},{ }^{226} \mathrm{Ra}$ or ${ }^{210} \mathrm{~Pb}$, respectively, $\mathrm{r}$ - plant, $\mathrm{z}$ - soil and d/w - dry/wet mass. Physical and chemical properties of soil as $\mathrm{pH}$, relative humidity, soil type etc. influence on radionuclide transport and if we do not know these parameters, transfer factor could not be defined. For determining transfer factor soil - plant usually $10 \mathrm{~cm}$ thick layer of soil is considered.

Main source of ${ }^{210} \mathrm{~Pb}$ in the environment is decay of ${ }^{222} \mathrm{Rn}$ in the atmosphere. ${ }^{210} \mathrm{~Pb}$ falls on the plant by deposition (rainfall) or sedimentation. The second possible path is migration from soil into the roots of plant and further into the stalk and leaves. Both paths are important for determination of transfer factor. Transfer factors for ${ }^{238} \mathrm{U},{ }^{226} \mathrm{Ra}$ or ${ }^{210} \mathrm{~Pb}$ are presented in table 1 [2, 3]. In brackets are the smallest and the biggest values measured.

\subsection{Specific activities of natural radionuclides in soil and grass samples}

We collected data on the measured specific activities of natural radionuclides ${ }^{238} \mathrm{U},{ }^{226} \mathrm{Ra}$ in ${ }^{210} \mathrm{~Pb}$ in samples of soil and grass in Slovenia for the last three years [4-7]. The geological structure of the land around the mine, on which the samples of soil and grass were taken, is different than in Slovenia in general, therefore the data is not statistically credible, it is only a rough estimate and not a precise calculation of the impact of migration of radionuclides from tailings in the food chain. Do not forget that the rock is covered with a $2 \mathrm{~m}$ thick layer of clay, soil and humus. In the evaluation, we considered only the results of measurements of specific activities of natural radionuclides in the protective layer, because the measurement of material in the upper layer has not been performed.

Table 2 represents specific activities of ${ }^{238} \mathrm{U},{ }^{226} \mathrm{Ra}$ and ${ }^{210} \mathrm{~Pb}$ in soil samples in Slovenia [4-7], in the surroundings of uranium mine area [10] and in covering material on depository Jazbec and Boršt $[8,9]$. 
Table 3. Specific activities of ${ }^{238} \mathrm{U},{ }^{226} \mathrm{Ra}$ and ${ }^{210} \mathrm{~Pb}$ in grass (Bq/kg dry mass).

\begin{tabular}{|l|c|c|c|}
\hline $\begin{array}{l}\text { Radionuclide/Location } \\
\text { Reference }\end{array}$ & $\begin{array}{c}\text { Slovenia } \\
{[4-6]}\end{array}$ & $\begin{array}{c}\text { Surroundings of } \\
\text { uranium mine } \\
{[11,12]}\end{array}$ & $\begin{array}{l}\text { Depository Jazbec } \\
{[11,12]}\end{array}$ \\
\hline${ }^{238} \mathrm{U}$ & $2.1(0.2-4)$ & $1.4(0.4-3.2)$ & $1.35(0.46-2.1)$ \\
\hline${ }^{226} \mathrm{Ra}$ & $2.3(0.5-3.9)$ & $1.1(0.4-2.8)$ & $1.05(0.4-2.8)$ \\
\hline${ }^{210} \mathrm{~Pb}$ & $11.3(2.8-25)$ & $29.7(14.5-62.5)$ & $29.7(14.5-62.5)$ \\
\hline
\end{tabular}

Table 4. Calculated and measured specific activities of ${ }^{238} \mathrm{U},{ }^{226} \mathrm{Ra}$ and ${ }^{210} \mathrm{~Pb}$ in grass in Slovenia.

\begin{tabular}{|c|c|c|c|}
\hline $\begin{array}{l}\text { Reference } \\
\text { Radionuclide }\end{array}$ & $\begin{array}{c}\text { IAEA [2] } \\
(\mathrm{Bq} / \mathrm{kg}) \\
\text { calculated }\end{array}$ & $\begin{array}{c}\text { NRPB [3] } \\
(\mathrm{Bq} / \mathrm{kg}) \\
\text { calculated }\end{array}$ & $\begin{array}{c}\text { Slovenia }[4,5,7] \\
(\mathrm{Bq} / \mathrm{kg}) \\
\text { measured }\end{array}$ \\
\hline${ }^{238} \mathrm{U}$ & $1.18(0.86-1.65)$ & $0.21(0.15-0.29)$ & $2.2(0.2-4)$ \\
\hline${ }^{226} \mathrm{Ra}$ & $2.83(2.07-4.21)$ & $1.41(1.042 .10)$ & $2.3(0.5-3.9)$ \\
\hline${ }^{210} \mathrm{~Pb}$ & $0.10(0.05-0.16)$ & $3.60(1.83-5.67)$ & $11.3(2.8-25)$ \\
\hline
\end{tabular}

Table 5. Calculated and measured specific activities of ${ }^{238} \mathrm{U},{ }^{226} \mathrm{Ra}$ and ${ }^{210} \mathrm{~Pb}$ in grass in surroundings of uranium mine.

\begin{tabular}{|l|c|c|c|}
\hline Reference & $\begin{array}{c}\text { IAEA [2] } \\
\text { Radionuclide } \\
\text { calculated }\end{array}$ & $\begin{array}{c}\text { NRPB [3] } \\
(\mathrm{Bq} / \mathrm{kg}) \\
\text { calculated }\end{array}$ & $\begin{array}{c}\text { Surroundings of uranium } \\
\text { mine }[11,12] \\
(\mathrm{Bq} / \mathrm{kg}) \\
\text { measured }\end{array}$ \\
\hline${ }^{238} \mathrm{U}$ & $1.48(1.02-1.86)$ & $0.26(0.18-0.32)$ & $1.4(0.4-3.2)$ \\
\hline${ }^{226} \mathrm{Ra}$ & $6.11(5.0-7.88)$ & $3.05(2.50-3.94)$ & $1.1(0.4-2.8)$ \\
\hline${ }^{210} \mathrm{~Pb}$ & $0.12(0.07-0.14)$ & $4.21(2.70-5.20)$ & $29.7(14.5-62.5)$ \\
\hline
\end{tabular}

Specific activities of ${ }^{238} \mathrm{U}$ are the highest in covering layer, in the surroundings of uranium mine are about $10 \%$ higher than in Slovenia. Specific activities of ${ }^{226} \mathrm{Ra}$ are the highest in the surroundings of uranium mine Žirovski vrh. Specific activities of ${ }^{226} \mathrm{Ra}$, measured in covering layer of the depository are lower than in the vicinity of uranium mine. Specific activities of ${ }^{210} \mathrm{~Pb}$, are $89.9 \mathrm{~Bq} / \mathrm{kg}$ in Slovenia, 105.3 $\mathrm{Bq} / \mathrm{kg}$ in mine area and and $70.7 \mathrm{~Bq} / \mathrm{kg}$ in covering layer. Specific activities of ${ }^{238} \mathrm{U},{ }^{226} \mathrm{Ra}$ and ${ }^{210} \mathrm{~Pb}$ in soil samples taken from surroundings of uranium mine are higher than in other territory of Slovenia.

Table 3 represents specific activities of radionuclides ${ }^{238} \mathrm{U},{ }^{226} \mathrm{Ra}$ in ${ }^{210} \mathrm{~Pb}$ grass samples in Slovenia [4-6], surroundings of mine area [11, 12] and on the depository Jazbec [11, 12].

Specific activities of ${ }^{238} \mathrm{U}$ and ${ }^{226} \mathrm{Ra}$, measured in samples in territory of Slovenia are higher than in samples from surroundings of uranium mine. Specific activities of ${ }^{210} \mathrm{~Pb}$ in grass samples from uranium mine are higher than in Slovenia, what is caused by higher radon concentrations in the air in mine area.

\subsection{Transfer soil - grass}

From measured specific activities of ${ }^{238} \mathrm{U},{ }^{226} \mathrm{Ra}$ and ${ }^{210} \mathrm{~Pb}$ in samples from Slovenia, surroundings of uranium mine and covering layer (Table 3), transfer factors $\mathrm{TF}$ from [2, 3], (Table 1) and equation 1, expected specific activities of radionuclides ${ }^{238} \mathrm{U},{ }^{226} \mathrm{Ra}$ and ${ }^{210} \mathrm{~Pb}$ in grass were calculated (Tables 4, 5, 6). Measured and calculated values of specific activities of natural radionuclides ${ }^{238} \mathrm{U},{ }^{226} \mathrm{Ra}$ and ${ }^{210} \mathrm{~Pb}$ in grass samples for depository Jazbec are presented on figures 1,2 and 3. 


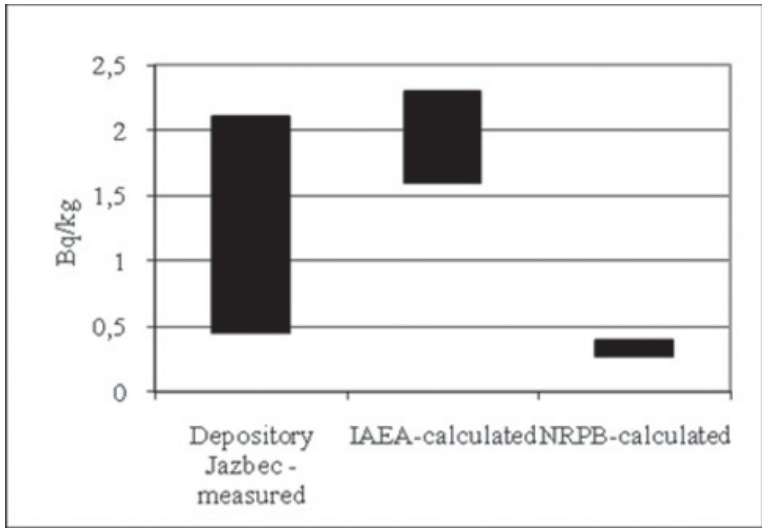

Figure 1. Calculated and measured specific activities of ${ }^{238} \mathrm{U}$ in grass on the depository Jazbec.

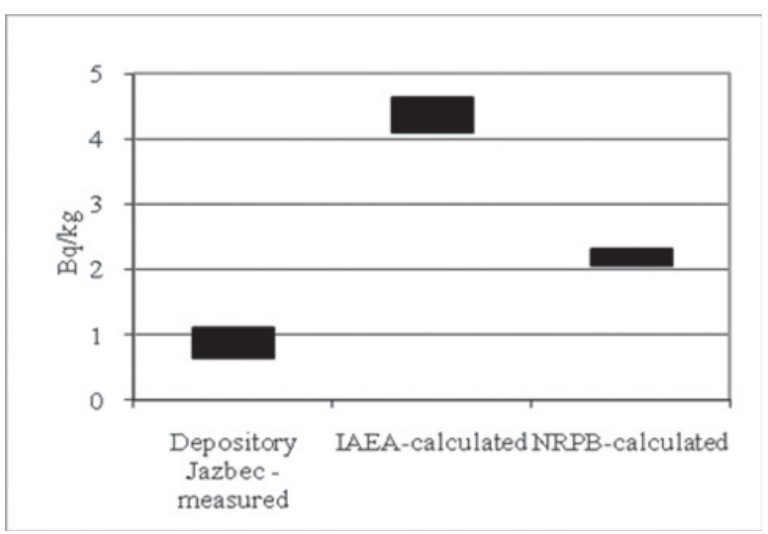

Figure 2. Calculated and measured specific activities of ${ }^{226} \mathrm{Ra}$ in grass on the depository Jazbec.

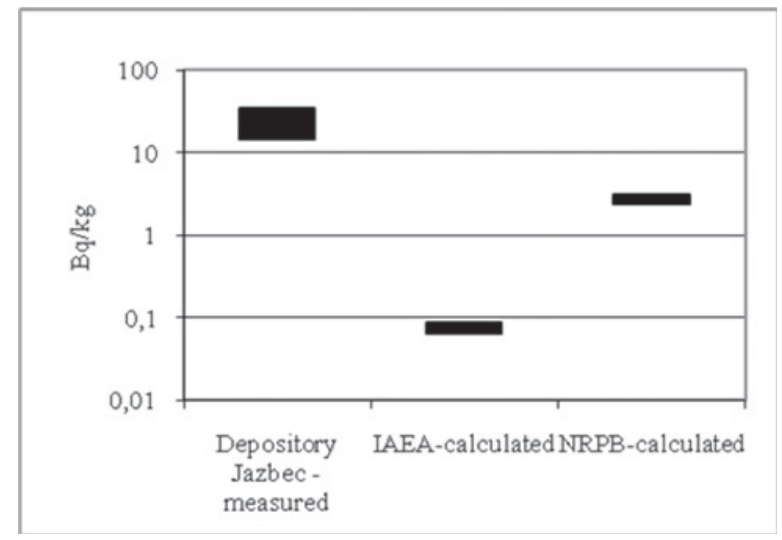

Figure 3. Calculated and measured specific activities of ${ }^{210} \mathrm{~Pb}$ in grass on the depository Jazbec. 
Table 6. Calculated and measured specific activities of ${ }^{238} \mathrm{U},{ }^{226} \mathrm{Ra}$ and ${ }^{210} \mathrm{~Pb}$ in grass on the depository Jazbec.

\begin{tabular}{|l|c|c|c|}
\hline $\begin{array}{l}\text { Reference } \\
\text { Radionuclide }\end{array}$ & $\begin{array}{c}\text { IAEA [2] } \\
(\mathrm{Bq} / \mathrm{kg}) \\
\text { calculated }\end{array}$ & $\begin{array}{c}\text { NRPB [3] } \\
(\mathrm{Bq} / \mathrm{kg}) \\
\text { calculated }\end{array}$ & $\begin{array}{c}\text { Depository Jazbee [11,12] } \\
(\mathrm{Bq} / \mathrm{kg}) \\
\text { measured }\end{array}$ \\
\hline${ }^{238} \mathrm{U}$ & $1.89(1.60-2.29)$ & $0.33(0.28-0.40)$ & $1.35(0.46-2.1)$ \\
\hline${ }^{226} \mathrm{Ra}$ & $4.39(4.09-4.62)$ & $2.19(2.05-2.31)$ & $1.05(0.4-2.8)$ \\
\hline${ }^{210} \mathrm{~Pb}$ & $0.08(0.07-0.08)$ & $2.83(2.37-3.07)$ & $29.7(14.5-62.5)$ \\
\hline
\end{tabular}

\section{CONCLUSIONS}

If we compare specific activities of ${ }^{238} \mathrm{U}$ in ${ }^{226} \mathrm{Ra}$ with calculated activities, we can see that they are a good match. The biggest difference is on the landfill Jazbec, where both calculated values of specific activity are above the measured specific activity of this radionuclide. The reason is probably due to the fact, that, when calculating, the specific activities of ${ }^{226} \mathrm{Ra}$ in the protective layer have been taken into account. It has been done this way, because the results of measurements of soil and humus above the protection layer do not exist, but values in soil and humus, which are from another, are lower.

Big difference between the calculated and measured values of specific activities is visible in ${ }^{210} \mathrm{~Pb}$. In the area of Slovenia values are normal, but in an environment of Žirovski vrh and landfill Jazbec the measured specific activity of ${ }^{210} \mathrm{~Pb}$ goes far beyond the calculated specific activity of this radionuclide. The reason is the concentration of radon and his progeny, which is, compared to the rest of Slovenia, higher around the Žirovski vrh mine.

\section{References}

[1] Rudnik urana Žirovski vrh, Odlagališče rudarske jalovine Jazbec, Varnostno poročilo: UZJV B103/048A, Revizija A, IBE, IJS, ZVD, 2005.

[2] IAEA 1994. Handbook of Parameter Values for the Prediction of radionuclide Transfer in Temperate Environments, Technical Report 364.

[3] NRPB-W49. Rewiew of the Transfer of Naturally Occuring Radionuclides to Terrestrial Plants and Domestic Aimals, NRPB 2003.

[4] Radioaktivnost v življenjskem okolju Slovenije za leto 2006, ZVD, 2007.

[5] Radioaktivnost v življenjskem okolju Slovenije za leto 2007, ZVD, 2008.

[6] Poročilo o izvedbi monitoringa radioaktivnosti živil za leto 2008, ZVD, 2009.

[7] Poročilo o izvajanju monitoringa radioaktivnosti v življenjskem okolju v Republiki Sloveniji za leto 2008, ZVD, 2009-

[8] Poročilo o meritvah radioaktivnosti, LMSAR-20080042a-PJ, ZVD, 2008.

[9] Poročilo o opravljenih meritvah izhajanja radona iz tal na poskusnem polju prekrivke na jalovišču Jazbec (prekrivna plast na spodnji polovici poskusnega polja, uvaljana), LMSAR-189/2003-PJ, ZVD, 2003.

[10] Meritve radioaktivnosti v okolju rudnika Žirovski vrh in ocena vplivov na okolje, rezultati za leto 2005, IJS, 2006.

[11] Poročilo o meritvah specifičnih aktivnosti radionuklidov v vzorcih trave, LMSAR-20080034-PJ, ZVD, 2008.

[12] Poročilo o meritvah specifičnih aktivnosti radionuklidov v vzorcih trave, LMSAR-20080039-PJ, ZVD, 2008. 